\title{
Management Accounting Systems, Top Management Team's Risk Characteristics and Their Effect on Strategic Change
}

\author{
Nikolaos Theriou ${ }^{1}$ Vassilis Aggelidis
}

\begin{abstract}
:
Globalization intensifies world competition which leads to continuous market and industry changes that force the majority of organizations to reconsider their strategic position and engage in strategic changes, mostly, through continuous innovation and new product development with smaller life cycles. These strategic actions have developed an environment with increased complexity, uncertainty and risk. On the other hand, organizations differ in their ability to realize strategic changes, depending on many factors that affect their strategic management process. The aim of this paper is to examine the effect of TMTs risk characteristics (risk propensity, risk perception and risk taking), on the extent of strategic change both, directly and indirectly, through the design and use of the management accounting system (MAS). The proposed research model is tested via a survey on 133 top management teams, from large size enterprises with more than 250 employees throughout Greece. Our finding suggest that (a) risk taking characteristic is determined by the other two risk characteristics of risk perception and risk propensity, and (b) there is a direct and a significant indirect relationship between TMTs' risk taking decisions and their strategic changes, affected by the intervening mediating role of the broad-scope and interactive use of MAS. The results of the study will help organisations to understand the significance of MAS use and the intervening effect on the relationship between TMTs risk characteristics and their strategic decision making process when considering new strategic changes.
\end{abstract}

Key Words: Risk Perception, Risk Propensity, Risk Taking, Management Accounting Systems, Strategic Change

JEL Classification: G32, M41

\footnotetext{
${ }^{1}$ Corresponding author: N. G. Theriou, Eastern Macedonia \& Thrace Institute of Technology, Agios Loukas, Kavala 65404, Greece, telephone: 00302510462371, fax: 00302510462148, email: ntheriou@ teiemt.gr
} 


\section{Introduction}

In the current business environment characterized by fast changes in customers, technologies and competition, organizations need to continuously renew themselves to survive and prosper (Danneels, 2002; Henri, 2006). Decision making concerning strategic changes for overcoming environmental pressures may have significant effect on firm's performance (Nyamori et al., 2001). Carpenter, Geletkanycz and Sander (2004) argue that the structure of firm's top managerial team has significant impact on strategic decision making and on the effectiveness of strategic change implementation.

However, our knowledge about the organizational factors and mechanisms that enable strategic change is incomplete and fragmented (e.g., Frow et al., 2005; Henri, 2006; Chenhall and Langfield-Smith, 2003), despite clear evidence across the management literature that organizations systematically differ in their inclination and ability to pursue strategic change (e.g., Abernethy and Brownell, 1999; Lant and Montgomery, 1987; Wiersema and Bantel, 1992). The strategic management literature, for example, suggests that the composition of the organization's top management team (TMT), which is the echelon ultimately responsible for strategy development and deployment, affects the strategic choices of the organization, and the ability to execute them (see, e.g., Carpenter, Geletkanycz, and Sanders, 2004).

Several studies following the so-called upper echelon (UE) perspective show that TMT heterogeneity, which is the extent to which the team consists of managers with varying backgrounds and competences, systematically varies with the organization's inclination and ability to engage in strategic change (e.g., Hambrick and Mason, 1984; Finkelstein and Hambrick, 1996; Golden and Zajac, 2001; Jarzabkowski and Searle, 2005; Naranjo-Gil and Hartmann, 2007).

Others argue that although research on upper echelons reveals the importance of TMTs, CEO's are rarely distinguished from the TMT as a whole (Jackson, 1992). It is obvious, from everyday observation and a wealth of related literature, that the top group leader has a disproportionate, sometimes nearly dominating influence on the group's various characteristics and outputs (Peterson et al., 2003).

Moreover, the potential for ambiguity associated with underlying phenomena has led numerous scholars to argue that more questions remain or have been created by UE research than have been answered suggesting that demographics should be abandoned in favor of richer variables with more substantive dimensions, like processes, attitudes and judgments (Priem et al., 1999) or top management cognition, values, and perspectives, and, consequently, strategic choices (Carpenter et al. 2004). A movement away from the use of demographics as proxies is likely to provide 
greater insight into the actual activities of senior managers, and the actual processes by which executive's impact organizational outcomes (Lawrence, 1997).

The various corporate frauds, especially in our days, and the world economic crisis that we live today, make risk to be more important than ever, increasing the interest in assessment and risk management to a level where "it is more important than ever before" (Lam, 2006). Firms have to operate in an environment which hides a number of threats and opportunities.

Although up to 1980's and 1990's management brought up a number of tools and techniques reducing risk, which resulted in the economic growth of corporations, during the last twenty years the unstable economic, political and competitive climate have brought back the concept of risk. Brouthers (1995) regards risk as key influence in the decision of a firm to enter a new market but also to choose the entry mode. Firms, especially those operating on industries with high level of uncertainty, would like to find ways to reduce risk. The potential of a strategic failure is not the worst scenario only for the firm but also for a number of stakeholders such as the employees, shareholders and suppliers. Everybody within a firm wants to be sure that the firm has taken all of the necessary measures to reduce risk.

Besides the avoidance of a failure, there is another view of risk; the lucrative one. According to Chen (2009) during the last decade most of the well known startups were on sectors with high risks while most of the new ventures that operated as boosters of their economies were firms that decided to take up the risk and to enter new markets with high risk, such as the computing industry. During the 90's and 00 's we noticed tens of new ventures that invested billions of dollars into new projects and entrepreneurs in order to create new markets or increase their market share. Basu et al (2008) empirically found that the more risky a market is the higher is the probability for a firm to have high long term benefits if it manages to survive, or huge losses if it does not manage the risks properly and effectively.

In general, there is the assumption that decision makers prefer less risky decisions in times of high uncertainty, such as the one we live today. However, managers can choose from a variety of management tools, such as management accounting systems (MAS), to moderate the environmental uncertainty. For example, Naranjo et al. (2007) argue that MAS can be used by a variety of business in order to improve the quality of the information received from the external and internal business environment and used by top managers in order to take risk decisions under a continuous changing complex environment with high risk and uncertainty.

The aim of this paper is to examine the basic risk characteristics of top managers, based on risk theory, and their direct and indirect effect, through the use of management accounting systems (MAS), on the strategic change of the firm. 
Having in mind the fact that we live in an economic turmoil, it is crucial to measure the views of the top managers, including those of the CEOs, of Greek large firms in terms of how much risk they are prepared to take in order to lead their companies to the necessary changes in accord with the changes occurring on their external environment.

The remainder of this paper is structured as follows. Section "Literature review and hypotheses development" reviews the literature and develops hypotheses about the relationships between TMT risk characteristics ( risk perception, risk propensity, and risk taking decision making), the use of MAS and strategic change. Section "Empirical study" describes the method. Section "Results" presents the results of the empirical analysis. Finally, section "Discussion and conclusions" presents the discussion and conclusions of this study.

\section{Literature Review and Hypotheses Development}

\subsection{TMT Risk Taking Decision and Strategic Change}

We begin our literature review with a definition of TMT which, we believe, suits to the Greek context of our research sample, i.e., large companies employing more than 250 employees: TMT members are senior executives, who also served on the board of directors (Finkelstein and Hambrick, 1990; Haleblian and Finkelstein, 1993; Norburn, 1989). This implies that CEO is also a member of the TMT.

In their original thesis, HandM were explicit in arguing the need to focus on the top management team as opposed to other units, most especially the CEO alone. Their collectivist approach was born of observations that strategic choice is an arduous task, far exceeding the capabilities of individual executives (Cyert and March, 1963). In subsequent research Hambrick (1994) instituted a challenge to the TMT label, arguing that top management group (TMG) may be a more apt moniker given the high potential for intrateam fragmentation. Among the greatest benefits of this reframing is attention to the diverse array of interactions and configurations possible within senior organizational ranks (e.g., competitive, coalescing). However, a shift from TMT to TMG label nevertheless maintains emphasis on the broader collectivity of senior management.

The management literature on strategic choice (e.g. Child, 1972; Hrebiniak and Joyce, 1985), and on the role of upper echelons (UE) in strategic management (e.g., Carpenter et al., 2004; Hambrick and Mason, 1984) both emphasize the importance of TMTs in the formulation and implementation of an organization's strategy. The latter perspective seeks to explain strategic choices of organizations by the composition of their upper echelons, claiming that organizations' strategic directions can be explained by the demographic backgrounds of TMT members. 
However, they also state that "it is doubtful that this research stream can progress far without greater attention to relevant literature in related fields, especially psychology and social psychology" (Hambrick and Mason, 1984, p. 203).

Wiersema and Bantel (1992), for example, argued that because of different values, experiences and cognitive make-up, top managers differ in their inclination and ability to change organizational strategies when they are confronted with competitive or other external pressures. Indeed, addressing turbulence and dynamism require specific managerial skills and competences, the availability of which varies across individual managers, and across the management teams they operate in. Priem et al. (1999) suggested that demographics should be abandoned in favor of richer variables having more substantive dimensions including processes, attitudes and judgments.

Finally, Carpenter et al. (2004), stated that it is critical to recall that the practice of using demographic proxies is only a methodological convenience. Demography is used to proxy larger, complex, and hard-to-get-at constructs. Demography itself is not the key theoretical driver of strategic processes and choices. Rather, the theoretical model posits that cognitions, values, and perceptions affect strategic choice. Consequently, with recent developments in measures, there is ample opportunity for scholars to supplement simplistic measures of demographic profiles with richer measures of top management cognition, values, and perceptions and, consequently, strategic choices. The work of Peterson et al. (2003), for instance, provides dramatic evidence of the impact of CEOs on firm performance through their effect on TMT dynamics.

In our case, the relationship between TMT risk taking decisions and strategic change will be examined. Risk is not easy to be defined (Skipper, 1997), though risk is used from managers to judge the potential threats from a decision that they are about to take (Shimpi, 2001). Risk is found on every firm and industry, hence a manager, executive or even a junior employee is obliged to take some risk. The risk is linked with the ability to understand when a decision lead into a deviation from the industry's standard paths and therefore to a failure (Gupta, 2004). Li (2009) states that, in the business world, a risk taker has much different characteristics from an adventurer or a gambler. However, in some cases, he has to use his luck when the time requires a decision to be taken. However a decision maker that wants to take some risks must develop critical analysis traits. For Jorion (2001) the risk taker must have a sound understanding of the market and how it works. He must sense the threats and be ready to provide a genuine solution. This means that the risk taker has developed a good experience of the market but also he is able to work with his senses. His experience may say which decision is risky and which is not. Even if it's a risky one, he must be able to judge the level of risk and how the firm can avoid this risk. 
Audia et al. (2000) believe that firms that want to be pioneer and gain a momentum against their competitions must take the risk to make changes. An example is GE, which made a number of high risk changes during the 80 's, on some occasions those changes were pretty risky such as job layoffs and investments, but in the end GE manage to get away from the crisis.

High risk taking decisions can be found in firms which are pioneers in change. Previous research indicates that pioneers often encounter significant challenges to their viability (Robinson and Min, 2002; Min et al., 2006). For example, pioneers frequently deal with customer needs and technologies that are rapidly evolving (Carpenter and Nakamoto, 1989; Kerin et al., 1992). Given that market pioneering is widely regarded as a risky activity (Golder and Tellis, 1993; Min et al., 2006), the extent to which top management uses a decision making style that accepts risk may be critical to adopting a strategy of market pioneering.

According to Narayanan (2001), firms engaging in new products or markets development are considered as pioneers. This means that those pioneering acts hide many risks. This is quite popular with firms that operate in the high technology and similar industries. The principal impetus can be a new product or service which will be launched in the markets for the very first time. The firms that belong to this industry will take a high risk that may require important strategic changes. We can recall how Apple from an IT firm ended up a firm producing mobile phones and other non-computing products. Allen (2003) claims that radical changes may be needed also to avoid risks or to enforce a risky decision. Someone who seeks to be the first entrant in a market, thereby to be called a pioneer, must be ready to make extended strategic changes so as to minimize the risks involved.

Garret et al. (2009) point out that firms willing to take risks must also be prepared to commit in changes. They argue that managers and top executives who are willing to take the risk will also have a positive reaction to strategic change. Therefore we can formulate our first hypothesis:

H1: TMT risk taking decisions is positively related to strategic change

Risk perception, risk propensity, and risk taking decisions

\section{Risk perception and decision-making}

While numerous studies have been conducted on decision-making, there appear to be few examples in which risk perception was either directly manipulated or actually measured. Although researchers generally agree that there is a relationship between perception and decision-making (Keyes, 1985; Bromily and Curley, 1992; Krueger and Dickson, 1994; Sutcliffe, 1994), there are inconsistencies concerning the nature 
of the relationship. One would expect that as the level of perceived risk increases, a person is less likely to engage in risk-taking behavior (Staw et al., 1981; March and Shapira, 1987; Dunegan et al., 1992), but there is evidence indicating that this is not always the case. For example, Kahneman and Tversky (1979) have found that under negative problem framing, decision-makers perceiving high levels of risk respond with risk-seeking behavior.

There is some empirical literature on the role of risk perception in entrepreneurship and management but it offers little evidence on its effect on business performance. Antonides and Van der Sar (1990) show that risk perception has an effect on the expected profitability of holding stocks and thus on the investment decision making of Dutch investment clubs but they do not consider actual returns. Koellinger, Minniti, and Schade (2007) and Simon, Houghton, and Aquino (1999) show that perceptions also matter in the decision to start a business. Finally, Willebrands et al. (2011) found a positive effect between risk perception and business success.

\section{Risk propensity and decision-making}

An individual's propensity to take or avoid risks may have a significant impact on decision-making under conditions of risk and uncertainty. It has been commonly observed that people differ in their willingness to take risks (Fishburn, 1977; MacCrimmon and Wehrung, 1990; Farmer, 1993; Fu, 1993), but there is disagreement about the nature of this trait and the impact it has on decision-making. One possibility is that risk propensity is a general personality trait which causes individuals to demonstrate consistent risk-seeking or risk-averse tendencies across a variety of situations. This possibility has led to the development of instruments which attempt to measure an individual's general risk propensity (Kogan and Wallach, 1964; Jackson et al., 1972; Harnett and Cummings, 1980). For example, Keinan et al. (1984) developed a risk propensity instrument in an attempt to identify individuals who have high risk-taking propensities. They based the development of their instrument on the "assumption that risk-taking is an expression of personality traits that affect individuals beyond situational variables" (Keinan et al, 1984, p. 163). Similar instruments have been used in a number of studies and the results have suggested that individuals have a general risk propensity which affects their decision-making under conditions of risk or uncertainty (Taylor and Dunnette, 1974; Ghosh and Ray, 1992; Kim, 1992).

Other studies, however, have found risk propensity to be a situationally - specific variable, meaning that an individual 's risk propensity will not be the same in every situation (MacCrimmon and Wehrung, 1985). A large number of researchers have found no evidence of a general risk propensity across situations (Slovic, 1962; Kogan and Wallach, 1964; Higbee, 1971; Slovic, 1972; Keyes, 1985; MacCrimmon and Wehrung, 1990). Rather, the bulk of the evidence shows more support for "the 
importance of situational factors than support for the notion of risk-taking propensity as a stable trait" (Slovic, 1972, p.133). Therefore, in order to predict an individual's decision-making in a particular risk context, it is necessary to examine the individual's risk propensity in a similar situation (MacCrimmon and Wehrung, 1985). This suggests, for example, that if one is interested in predicting decisionmaking in a strategic context, then it is necessary to examine risk propensity in situations concerning strategic decision-making. We turn now to the relationship between risk propensity and risk perception.

\section{Risk propensity and risk perception}

Although risk propensity and risk perception both appear to influence decisionmaking, there is also evidence indicating that they interact with each other as well. More specifically, it appears that risk propensity may have an impact on risk perception. For example, if an individual has a high risk-taking propensity, he/she may tend to underestimate the risks involved in a situation. A risk-seeking decision maker is more likely to recognize and weigh positive outcomes, thereby overestimating the probability of a gain relative to the probability of a loss (Brockhaus, 1980; Vlek and Stallen, 1980). This overestimation will result in a lowering of risk perceptions. Additionally, a risk-averse decision maker will weigh negative outcomes more highly, leading to a heightened perception of risk (Schneider and Lopes, 1986). Forlani and Mullins (2000), examining the perceived risks and choices in entrepreneurs' new venture decisions, concluded that there is no statistically significant relationship between the risk propensity of the entrepreneur and his perceived risk associated with a particular new venture.

To conclude, the exact nature of the relationship between risk perception, risk propensity, and risk decision-making is not well understood. While prior research has examined the effects of risk perception on decision-making and the relationship between risk propensity and decision-making, we know of only two studies that have examined all three constructs together (Sitkin and Pablo, 1992; Keil et al., 2000). Sitkin and Pablo (1992, p. 12), synthesizing much of the literature on risk taking behavior, define three key variables: risk preference, risk perception and risk propensity. For risk preference they refer to decision makers who enjoy the challenge risks entail. Risk perception is defined as a decision maker's assessment of the risk inherent to a situation. Risk propensity is conceptualized as an individual's actual risk-taking tendency. There is, however, no agreement in the literature on how the three key variables are related. The view of Sitkin and Pablo (1992) is that, the propensity to take risks is partly determined by the risk preference of the decision maker, as one would expect, but they also suggest that risk propensity influences risk perception. In an experimental setting, Sitkin and Weingart (1995) conversely show that risk perception completely mediates the effect of risk propensity on risky decision making behavior: risk propensity negatively affects risk perception but has 
no direct effect on risk taking behavior, while risk perception has a significant (negative) effect on risk taking behavior. On the other hand, Keil et al. (2000), in their undertaken experiment, found evidence to support only a significant negative relationship between risk perception and risk taking.

Because of this inconsistency and because of the lack of other empirical studies on the inter-relationships between these three constructs, there is a clear need for further study to see if the results obtained by Sitkin and Weingart (1995) are replicable. Forlani and Mullins (2000), examining the perceived risks and choices in entrepreneurs' new venture decisions, concluded that there is a statistically significant relationship between risk perception and the strategic decision taken (to create a new venture). They also found a statistically significant relationship between risk propensity and the strategic decision taken (to create a new venture), and no significant statistical relationship risk propensity has no effect on risk perception. Consequently, both their results agree with those of Sitkin and Pablo (1992).

Based on above review of risk literature the following hypotheses were formulated:

$\mathrm{H} 2$ : Less risk perception lead TMT members to take more risky decisions and actions (i.e., actions that have a high possibility of disappointing outcomes) because they perceive less risk than more. Thus, there will be a negative relationship between risk perception and risk taking decisions.

H3: The higher a decision maker's risk propensity, the lower the level of perceived risk. Thus, there will be a negative relationship between risk propensity and risk perception.

H4: The higher a decision maker's risk propensity, the higher is his/her risk taking behavior. Thus, there will be a positive relationship between risk propensity and risk taking decisions.

Risk taking decisions, management accounting systems, and strategic change

Risk taking decisions and management accounting systems (MAS)

Based on a review of the upper echelon literature, Miller et al. (1998, p. 40) conclude that 'the mediating effects of process variables have not been examined in most studies of executive diversity and organizational outcomes'. Similarly, Carpenter et al. (2004, p. 763) labels these process factors as the 'black box' of upper echelon research.

Traditionally, MAS have been associated with mechanistic organizations (Burns and Stalker, 1961), where their purpose was to reduce variety and implement standardization as portrayed in the cybernetic model (Ashby, 1960; Anthony, 1965). 
Accordingly, they were frequently perceived as a hindrance to any innovation and change effort in the organization. Recent theory and empirical studies have questioned the traditionally held assumptions about the negative effect of MAS on innovation and change, and highlighted instead the positive effect that MAS may have on innovation (Chapman, 1998; Abernethy and Brownell, 1997; Lukka, 1988; Ahrens and Chapman, 2002, 2004; Zirger and Maidique, 1990; Cooper, 1995; McGrath, 1995: Brown and Eisenhardt, 1997; Nixon, 1998; Davila, 2000; Cardinal, 2001). They developed alternative interpretations to the command-and-control view. MAS should be flexible and dynamic, adapting and evolving to the unpredictable needs of innovation, but stable enough to frame cognitive models, communication patterns, and actions (Lorange et al. 1986; Simons, 1995; Fiol, 1996; Abernethy and Brownell, 1999; Hoskisson et al. 1999; Gavetti and Levinthal, 2000; Miner et al. 2001; Burgelman, 2002; Feldman and Rafaeli, 2002; Bisbe and Otley, 2004; Chenhall, 2005).

As the recent management accounting literature generally suggests that MAS design and use is a relevant component of strategic management (Gerdin and Greve, 2004; Langfield-Smith, 1997), we could argue that MAS is likely to be such a mediator of the relationship between TMT risk characteristics and strategic change (Naranjo-Gill and Hartmann, 2007). Moreover, the upper echelon literature emphasizes that TMTs formulate their strategic decisions through their search, interpretation and 'filtering' of information about the external and internal environment of their firms, typically provided, mainly, by their established MAS (Hambrick and Mason, 1984; Knight et al., 1999; Miller et al., 1998). We expect that the typical searching and filtering behavior of top managers will be reflected in TMTs' use of the MAS in making and executing strategic decisions (Langfield-Smith, 1997; Abernethy and Brownell, 1999; Young et al., 2001; Chapman, 2010).

\section{Risk taking decisions and the use of MAS}

The TMT literature predicts that TMTs will differ in the scope of the management information that they consider useful in the (strategic) decisions that they take (Finkelstein and Hambrick, 1996; Jarzabkowski and Searle, 2005; Knight et al., 1999). The scope of MAS has often been associated with strategy, under the expectation that a broader range of information allows managers to better understand the relationship between activities, processes and strategic outcomes (Abernethy and Guthrie, 1994; Chenhall and Morris, 1986; Gerdin, 2005a; Gul, 1991; Gul and Chia, 1994). Mia and Chenhall (1994, p. 4) showed that broad scope ${ }^{2}$ MAS information is

2 Broad-scope MAS information is information that is 'externally focused, non-financial, and future oriented' (Bouwens and Abernethy, 2000. p. 223), which 'provides managers with a wider range of solutions to consider' (Bouwens and Abernethy, 2000. p. 226). Broad-scope information thus complements typical 'narrow scope' information, which reflects traditional management accounting 
crucial for managerial decision making, for example when organizations are facing complex situations, high environmental dynamism and strategic uncertainty (Abernethy and Guthrie, 1994, p. 55). Consequently, we believe that broad scope MAS information will be especially valued by TMTs, who are more inclined to change and innovation and take highly risky strategic decisions (Bantel and Jackson, 1989; Jensen and Zajac, 2004). Thus, we form the following hypothesis:

H5a: Risk taking is positively related to the perceived usefulness of broad-scope MAS.

Simons $(1995,2000)$ describes the diagnostic and interactive use of control systems arguing that the interactive use of MAS is essential for both enabling strategic change (Abernethy and Brownell, 1999, p. 192), and supporting innovation (Bisbe and Otley, 2004, p. 729). An interactive use of MAS involves dialogue and communication among top managers (Widener, 2006, p. 5), as well as between top management and subordinates, which 'stimulates opportunity-seeking and encourages the emergence of new initiatives (Simons, 1995, p. 93). Henri (2006, p. 5) asserted that when MCS are used interactively 'data are discussed and interpreted among organizational members of different hierarchical levels'.

We could thus assume that the riskier the decisions under consideration by TMT members the more the need for interactive use of MAS which stimulates dialogue and communication among top managers and between top managers and their subordinates for opportunity seeking and the emergence of new initiatives. Consequently, we propose to test the following hypothesis:

H5b: Risk taking is positively related to the interactive use of MAS.

\section{Use of MAS and strategic changes}

Empirical evidence suggest that the availability of a broader set of information facilitates and encourages management debates and interactions on strategic issues (Abernethy and Brownell, 1999, p. 192; Bisbe and Otley, 2004, p. 711).

Strategic change involves venturing into new contexts, whose complexity and unpredictability (Abernethy and Brownell, 1999, p. 191) requires broad-scope information (Bouwens and Abernethy, 2000. p. 226; Mia and Chenhall, 1994, p. 2). This suggests that the use of broad scope MAS is a necessary requirement for strategic change. In addition, broad-scope MAS information appears to facilitate

information that is 'internally focused, financial, and historically-based' (Bouwens and Abernethy, 2000. p. 223). 
interdepartmental planning and coordination (Bouwens and Abernethy, 2000), technological change (Mia and Chenhall, 1994, p. 1), decentralization (Gerdin, 2005b; Hartmann, 2005), customization (Perera, Harrison, and Poole, 1997), organizational flexibility, and the organization of interdependent operations (Abernethy and Lillis, 1995; Eccles, 1991, p. 131), which are all constitutive elements of prospector strategies, rather than of defender strategies (Shortell and Zajac, 1990). This suggests that broad-scope MAS supports strategic change, especially for organizations moving towards prospector positions. To explore these issues empirically, we propose to test the following hypothesis:

H6a: There is a positive relationship between the perceived usefulness of broadscope MAS and the extent of strategic changes.

A parallel point can be made regarding the relationship between the interactive use of the MAS and strategic change (Simons, 1995). Since the interactive use of MAS focuses on the use of information for dialogue and communication (Abernethy and Brownell, 1999; Simons, 1995), TMTs should use the MAS interactively when they aim to redefine or change strategic priorities. Abernethy and Brownell (1999, p. 192) asserted that management requires information 'that is more prospective in nature' and thus need an 'information exchange process that is interactive and dynamic' to manage strategic change effectively. Such a process enables management teams 'to collectively make sense of changing circumstances' (Chapman, 1997; Simons, 1995). Moreover, by stimulating organizational dialogue and debate, interactive MAS use contributes to the emergence of strategic actions (Henri, 2006, p. 9; Malina and Selto, 2001). Thus, we expect that the interactive use of MAS encourages and facilitates strategic change, and propose the following hypothesis:

H6b: There is a positive relationship between the interactive use of MAS and the extent of strategic changes.

\section{Broad scope of MAS and the interactive use of MAS}

Although Simons (1995) initially asserted that the interactive use of MAS could relate to any MAS aspect, thus suggesting the independence of these two factors, Bisbe and Otley (2004) and Abernethy and Brownell (1999) both argued that the use of broad scope MAS might not only facilitate, but also encourage debates and managerial interactions. We therefore propose to test the following hypothesis:

H7: There is a positive relationship between the perceived usefulness of broad-scope MAS and the interactive use of MAS.

Finishing our stated hypotheses we could now proceed to the proposed model that will be tested empirically: 
Figure 1: The Proposed Model

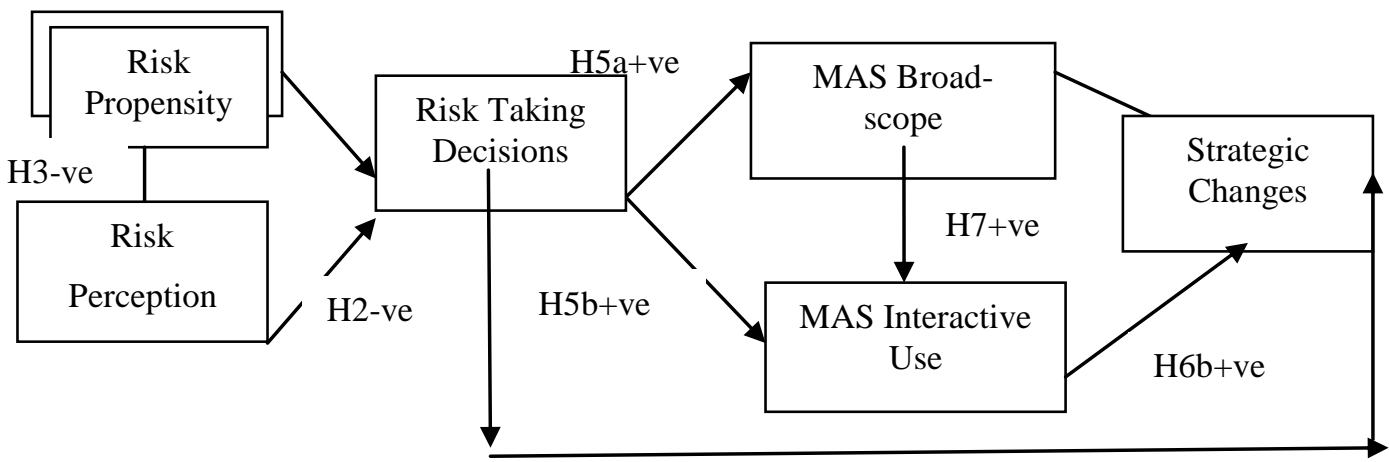

$\mathrm{H} 1+\mathrm{ve}$

\section{Research Methods}

\subsection{Data Selection}

To test the hypotheses, we collected data through a structured questionnaire, which was distributed to members of senior management team (TMT) of randomly selected enterprises employing more than 250 employees. In order to achieve sufficient sample size and generalizability of the result the initial sample for this study consisted of the total population of 506 large Greek companies. The population was drawn from a database compiled by ICAP, which is a well-known and reliable source of data for Greek companies. The size limitation was introduced for the reason that small and medium firms present some difficulties and mostly these companies do not have the appropriate strategic and management accounting tools (Chenhall and Langfield-Smith, 1998).

A pre-test was performed to establish content validity (Zikmund, 2003). The instrument was pre-tested through in-depth discussions with academics and professionals. Nine senior managers along with six academics participated in the pre-testing process. 
It should be mentioned that due to time constraints or company privacy concerns many senior managers declined to participate. 274 companies stated that it was against their policy to respond to research questions. The questionnaire was sent only to those senior managers of the 232 companies who agreed to participate in the survey (mailed or e-mailed, depending on their preference).

A cover letter explaining the study objectives was attached and a stamped return envelope was enclosed. Follow-up letters were sent approximately three weeks after the initial mailing. Since the number of members in the TMT may vary slightly, we consider as a full TMT those for which three observations, including that of the CEO, were available. Thus, we formed a total of 232 TMTs sending 696 questionnaires to be completed.

A total of 442 questionnaires were returned, which corresponds to a 63.50 per cent overall response rate. Of these, forty three (43) questionnaires were discarded because either they were not appropriately completed or some companies sent only one or two questionnaires instead of three. 399 questionnaires retained for analysis (a response rate of 57.33 per cent), forming a total of 133 TMTs from 133 firms. A brief presentation of the demographic characteristics is given in Appendix 1 (Table A2).

Generally speaking, researchers normally work at a 95 percent level of certainty. This actually means that with a total population of 506 firms the minimum sample size should be around 220 instead of 133 firms (Saunders, Lewis and Thornhill, 2000. p.156). Although the smaller size could be considered as one of the limitations of this research, we could defend it on the grounds stated by the famous scholar Shelby Hunt who argues that non-response bias does not consists a base rule for rejecting a manuscript, unless there are serious differences between respondents and non-respondents, therefore results are unreliable (Hunt, 1990).

To test whether our respondents were different from the non-respondents, we examined if there are any differences in the mean of all variables used in this study between early and late respondents. The rationale behind such an analysis is that late respondents (i.e. sample firms in the second mailing) are more similar to the population, from which they were drawn, than the early respondents (Armstrong and Overton, 1977). No statistically significant differences were found, thus suggesting that non-response bias is not a serious issue in the study.

According to current literature a sample size between 100 and 200 cases is adequate for small to medium size structural equation models. 


\subsection{Measurement of variables}

The survey questionnaire used for the measurement of the following six complicated constructs:

Risk perception was measured using four questions in which subjects were asked to indicate their perception of the overall risk associated with exports and selling of products in foreign markets along a five-point Likert scale, where $1=$ totally disagree and 5=totally agree (questions 1-4 from Sitkin and Weingart, 1995).

Risk propensity was based on a five-point Likert scale (where 1=very unlikely, and $5=$ very likely) and includes four questions (questions 5 to 8), which are related to the decision which affects the company's financial future (Kwon and Lee, 2009).

The risk taking was measured using statements from the risk scale taken from Miller and Friesen (1982), based on a five-point Likert scale and includes two questions, each one containing two statements (questions 9 to 10).

The interactive use of MAS was measured using six questions taken from NaranjoGil and Hartmann (2007) based on a five-point Likert scale, where 1= very little and $5=$ very much. Respondents were asked to indicate the extent of using the MAS for five managerial actions, for negotiating goals and targets, for encouraging new goals and priorities, for signaling key strategic areas, for encouraging new ideas and actions, for involving subordinates in face-to-face discussions and for use as a learning tool (questions 11 to 16 of the questionnaire).

The broad-scope MAS was measured using four questions taken also from NaranjoGil and Hartmann (2007), based on a five-point Likert scale, where 1= very little and $5=$ very much. Respondents were asked to indicate the extent of the usefulness of the following four types of information: future - oriented, external, non- financial and long-term information.

The Strategic Changes was measured using the instrument from Abernethy and Brownell (1999) and Abernethy and Lillis (2001). They used the strategic typology of Miles and Snow (1978). TMT managers were presented two descriptions, one of defender firm and another of a prospector firm, and were asked to indicate their firm's strategic position three years ago as well as their current strategic position, along a five point Likert-scale (where $1=$ defender and $5=$ prospector). Strategic change was measured as the absolute difference between the past and current strategic position. 


\subsection{Validation of Proposed Constructs}

It is well known that survey research, if not properly conducted, can provide misleading results with measurement errors representing one of the most significant sources of bias. While however, measurement errors are almost inevitable, the extent to which these errors affect the findings is a function of what particular efforts and what checks have been undertaken, in order to minimize and assess the potential bias.

On this account construct validation is particularly relevant. In effect it involves a multifaceted process comprising three basic steps. The first, content validity, requires the identification of a group of measurement items which are deemed to represent the construct of interest. The second step, construct validity, seeks to establish the extent to which the empirical indicators actually measure the construct. The final step, nomological validity, involves the determination of the degree to which a construct relates to other constructs in a manner predicated by theory. These issues are dealt with in Appendix 1, with the exception of nomological validity which is implicitly addressed in the context of the substantive relations examined in this study (see also note 2). All analyses (see Appendix 1 for detailed description of procedures and results) provide reasonable confidence that the measures used are valid and reliable.

\section{Results}

Data screening was performed to identify data entry errors and to examine whether data met all statistical assumptions. Then a preliminary descriptive analysis was performed in order to extract specific statistics (central tendency and dispersion) for the items included in the questionnaire. Then, test of data normality followed to check whether the used items are normally distributed and hence are accepted for further analysis. Skewness and kurtosis values of all data items are below 2 and 7 respectively, proving the normality of the data used (West et al. 1995). Correlation, exploratory and confirmatory factor analysis was also used to check the reliability and validity of the measurement model.

Then a two-step data analysis approach of the structural equation model was followed as suggested by Anderson and Gerbing (1988) to evaluate the goodness-offit of the structural models, i.e., separate estimation of the measurement model prior to the simultaneous estimation of the measurement and structural models ${ }^{3}$.

\footnotetext{
3 The measurement model in conjunction with the structural model enables a comprehensive, confirmatory assessment of construct validity. The measurement model provides a confirmatory assessment of convergent validity and discriminant validity. Given acceptable convergent and discriminant validities, the test of the structural model then constitutes a confirmatory assessment of nomological validity (Anderson and Gerbing, 1988).
} 
SPSS was used for the descriptive statistics and correlation analysis, while structural equation modeling techniques with Amos 7.0 were used to examine the models and all paths within the models.

Table 1 show the descriptive statistics for all variables and Table 2 shows the correlation analysis:

Table 1: Basic Statistics

\begin{tabular}{|l|c|c|c|}
\hline Factor & Mean & $\begin{array}{c}\text { Std. } \\
\text { Deviation }\end{array}$ & $\begin{array}{c}\text { Coefficient } \\
\text { of Variation }\end{array}$ \\
\hline Risk Propensity & 4.45 & 0.31 & $6.96 \%$ \\
\hline Risk Perception & 4.43 & 0.33 & $7.44 \%$ \\
\hline Risk Taking & 4.51 & 0.73 & $8.76 \%$ \\
\hline Interactive Use of MAS & 4.46 & 0.48 & $6.53 \%$ \\
\hline Use of Broad-Scope MAS & 4.53 & 0.27 & $5.96 \%$ \\
\hline Strategic Changes & 3.61 & 0.27 & $6.19 \%$ \\
\hline
\end{tabular}

Table 2: Correlation Analysis

\begin{tabular}{|l|l|c|c|c|c|c|}
\hline & \multicolumn{1}{|c|}{$\mathbf{1 .}$} & $\mathbf{2 .}$ & $\mathbf{3 .}$ & $\mathbf{4 .}$ & $\mathbf{5 .}$ & $\mathbf{6 .}$ \\
\hline 1. Risk Propensity & $\mathbf{1}$ & & & & & \\
\hline 2. Risk Perception & $-0.259^{*}$ & $\mathbf{1}$ & & & & \\
\hline 3. Risk Taking & $0.264^{*}$ & - & $\mathbf{1}$ & & & \\
\hline 4. Interactive Use of MAS & 0.040 & 0.065 & & $\mathbf{1}$ & & \\
\hline 5. Use of Broad-Scope MAS & 0.142 & 0.141 & & $0.463^{* * *}$ & $\mathbf{1}$ & \\
\hline 6. Strategic Changes & & & $0.524 * *$ & & & \\
\hline
\end{tabular}

*Correlation is significant at the 0.05 level

**Correlation is significant at the 0.01 level 
Figure 2 displays the results from the structural equation model path analysis using the maximum likelihood estimation (MLE) procedure of the SPSS-AMOS statistical package. Table 3 presents the direct, indirect, total effects (paths) and regression weights, and Table 4 the statistics for the overall fitting of the model. Seven common model-fit measures have been used to assess the model's overall goodness of fit: the ratio of $\mathrm{x}^{2}$ to degrees-of-freedom $\left(\mathrm{x}^{2} / \mathrm{df}\right)$, the comparative fit index $(\mathrm{CFI})$, the normalized fit index (NFI), the Tucker-Lewis Index (TLI), the root mean square residual (RMR), the root mean square error of approximation (RMSEA) and the goodness-of-fit index (GFI). Generally, good fits are obtained when CFI, NFI, TLI and GFI are equal or greater than .90 and RMR and RMSEA are equal to or less than 0.1 or.05 (Hair et al, 1998).

Figure 2: The Structural Model

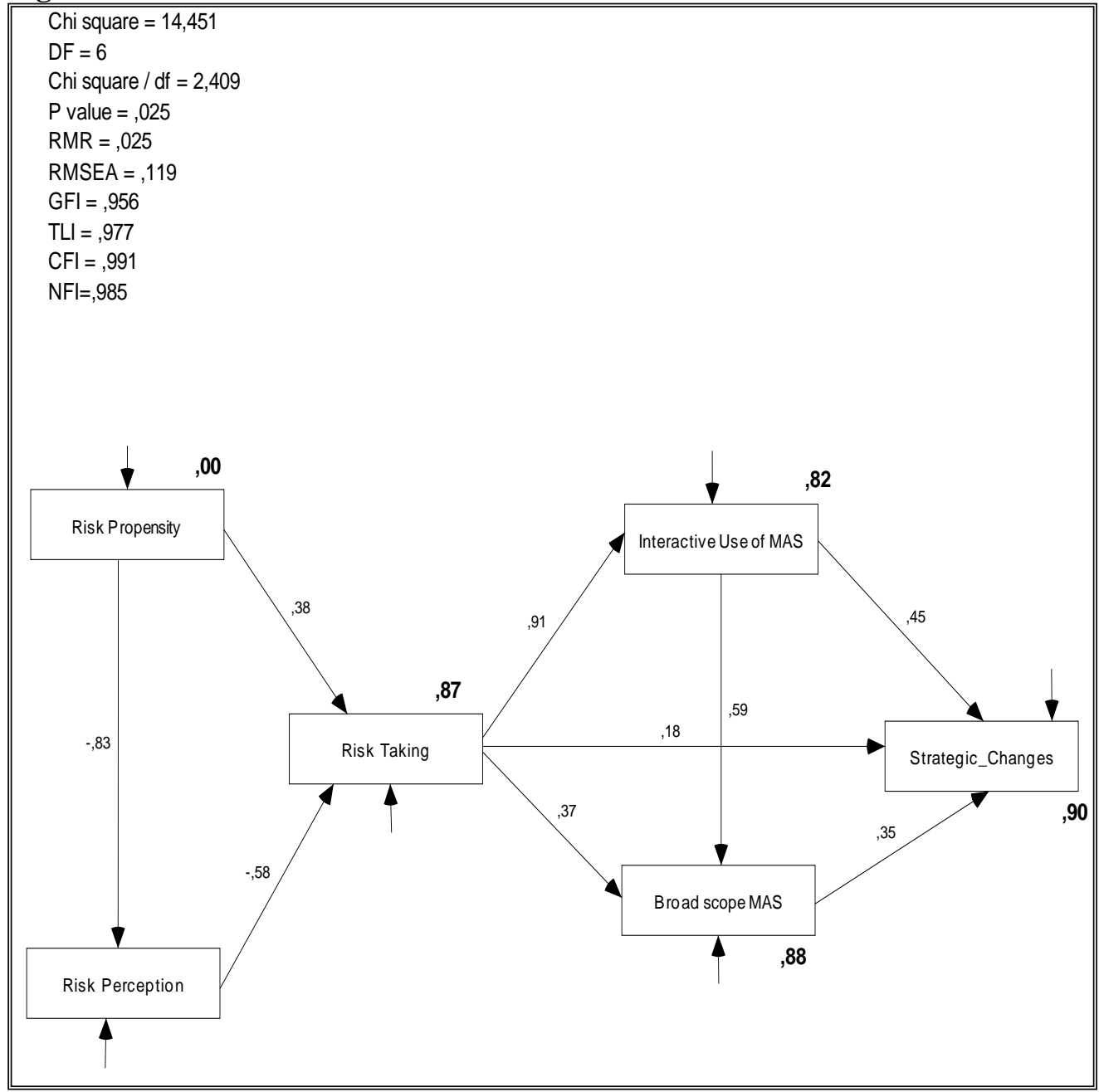


Table 3: Path Analysis

Standardized Total Effects

\begin{tabular}{|c|c|c|c|c|c|}
\hline & $\begin{array}{c}\text { Risk } \\
\text { Propensity }\end{array}$ & $\begin{array}{c}\text { Risk } \\
\text { Perception }\end{array}$ & Risk_Taking & $\begin{array}{c}\text { Interactive } \\
\text { Use of MAS }\end{array}$ & $\begin{array}{c}\text { Mas Broad- } \\
\text { scope }\end{array}$ \\
\hline Risk Perception & -0.834 & 0 & 0 & 0 & 0 \\
\hline Risk Taking & 0.872 & -0.585 & 0 & 0 & 0 \\
\hline $\begin{array}{c}\text { Interactive Use of } \\
\text { MAS }\end{array}$ & 0.790 & -0.530 & 0.906 & 0 & 0 \\
\hline MAS Broad-scope & 0.789 & -0.529 & 0.904 & 0.588 & 0 \\
\hline Strategic Changes & 0.785 & -0.526 & 0.899 & 0.657 & 0.347 \\
\hline
\end{tabular}

Standardized Direct Effects

\begin{tabular}{|c|c|c|c|c|c|}
\hline & $\begin{array}{c}\text { Risk } \\
\text { Propensity }\end{array}$ & $\begin{array}{c}\text { Risk } \\
\text { Perception }\end{array}$ & Risk_Taking & $\begin{array}{c}\text { Interactive } \\
\text { Use of MAS }\end{array}$ & $\begin{array}{c}\text { Mas } \\
\text { Broad- } \\
\text { scope }\end{array}$ \\
\hline Risk Perception & -0.834 & 0 & 0 & 0 & 0 \\
\hline Risk Taking & 0.384 & -0.585 & 0 & 0 & 0 \\
\hline $\begin{array}{c}\text { Interactive Use of } \\
\text { MAS }\end{array}$ & 0 & 0 & 0.906 & 0 & 0 \\
\hline MAS Broad-scope & 0 & 0 & 0.371 & 0.588 & 0 \\
\hline Strategic Changes & 0 & 0 & 0.176 & 0.453 & 0.347 \\
\hline
\end{tabular}

Standardized Indirect Effects

\begin{tabular}{|c|c|c|c|c|c|}
\hline & $\begin{array}{c}\text { Risk } \\
\text { Propensity }\end{array}$ & $\begin{array}{c}\text { Risk } \\
\text { Perception }\end{array}$ & Risk_Taking & $\begin{array}{c}\text { Interactive } \\
\text { Use of MAS }\end{array}$ & $\begin{array}{c}\text { Mas Broad- } \\
\text { scope }\end{array}$ \\
\hline Risk Perception & 0 & 0 & 0 & 0 & 0 \\
\hline Risk Taking & 0.488 & 0 & 0 & 0 & 0 \\
\hline $\begin{array}{c}\text { Interactive Use of } \\
\text { MAS }\end{array}$ & 0.790 & -0.530 & 0 & 0 & 0 \\
\hline MAS Broad-scope & 0.789 & -0.529 & 0.533 & 0 & 0 \\
\hline Strategic Changes & 0.785 & -0.526 & 0.724 & 0.204 & 0 \\
\hline
\end{tabular}


Regression Weights

\begin{tabular}{|c|c|c|c|c|c|c|}
\hline & & & Estimate & t. & $\begin{array}{c}\mathbf{p} \\
\text { value }\end{array}$ & \\
\hline Risk Perception & & Risk Propensity & -0.834 & -15.046 & $* *$ & $\begin{array}{c}\mathrm{H} 3 \\
\text { supported }\end{array}$ \\
\hline Risk Taking & & Risk Propensity & 0.384 & 5.746 & $* *$ & $\begin{array}{c}\mathrm{H} 4 \\
\text { supported }\end{array}$ \\
\hline Risk Taking & & Risk Perception & -0.585 & -8.74 & $* *$ & $\begin{array}{c}\mathrm{H} 2 \\
\text { supported }\end{array}$ \\
\hline $\begin{array}{c}\text { Interactive Use of } \\
\text { MAS }\end{array}$ & & Risk Taking & 0.906 & 21.236 & $* *$ & $\begin{array}{c}\mathrm{H} 5 \mathrm{~b} \\
\text { supported }\end{array}$ \\
\hline MAS Broad-scope & $\rightarrow$ & Risk Taking & 0.371 & 4.518 & $* *$ & $\begin{array}{c}\text { H5a } \\
\text { supported }\end{array}$ \\
\hline MAS Broad-scope & & $\begin{array}{c}\text { Interactive Use of } \\
\text { MAS }\end{array}$ & 0.588 & 7.158 & $* *$ & $\begin{array}{c}\mathrm{H} 7 \\
\text { supported }\end{array}$ \\
\hline Strategic Changes & $\longrightarrow$ & Risk Taking & 0.176 & 2.147 & $.032 *$ & $\begin{array}{c}\text { H1 } \\
\text { supported }\end{array}$ \\
\hline Strategic Changes & & $\begin{array}{c}\text { Interactive Use of } \\
\text { MAS }\end{array}$ & 0.453 & 4.936 & $* *$ & $\begin{array}{c}\text { H6b } \\
\text { supported }\end{array}$ \\
\hline Strategic Changes & & MAS Broad-scope & 0.347 & 3.815 & $* *$ & $\begin{array}{c}\text { H6a } \\
\text { supported }\end{array}$ \\
\hline
\end{tabular}

$* \mathrm{p}=0.05, * * \mathrm{p}=0.001$

Table 4: Overall Model Fit Indices

\begin{tabular}{|l|c|c|}
\hline \hline Indices & $\begin{array}{c}\text { Recommended } \\
\text { value }^{\text {a }} \\
\text { (cut-off limits) }\end{array}$ & $\begin{array}{c}\text { Values of the Measurement } \\
\text { Model }\end{array}$ \\
\hline \hline Chi- square & ----- & 14.451 \\
\hline d.f & ----- & 6 \\
\hline$\chi^{2} /$ d.f & $\mathbf{1 < \chi ^ { 2 } / \text { d.f } < 3}$ & $\mathbf{2 . 4 0 9}$ \\
\hline
\end{tabular}




\begin{tabular}{|l|c|c|}
\hline GFI & $>0.90$ & 0.956 \\
\hline NFI & $>0.90$ & 0.985 \\
\hline RMR & $<0.1$ & 0.025 \\
\hline RMSEA & $<0.1$ & 0.119 \\
\hline CFI & $>0.90$ & 0.991 \\
\hline
\end{tabular}

The overall model shows a chi-square/degree of freedom value of 2.409 having a pvalue of $<0.01$, indicating an excellent fit to the data. Moreover, comparative fit index (CFI) and general fit index (GFI), have a value of 0.991 and 0.956 respectively (i.e., more than 0.90 which is the cut-off point in both statistics), and RMR is $0.025<0.1$. They all indicate acceptable levels of model fit.

Table 3 presents the estimates (regression weights) of the structural model and their corresponding $\mathrm{t}$ values. According to these estimates we could come to the conclusion of accepting all hypotheses, since each relationship has got the proper sign, as was indicated by theory, and it is statistically significant at 0.001 (all hypotheses except H1) or 0.5 level (for H1). Moreover, the initial correlation analysis (table 2), figure 2 and the path analysis of table 3 indicate a strong verification of theory which supports and explains that the interactive use of MAS mediates the relationship between top management risk taking decisions and strategic change $(s)^{4}$ : (a) the single regression coefficient (or correlation coefficient) of the direct relationship between TMT risk taking (independent variable) and the strategic change (the dependent variable) is 0.314 (and statistically significant at 0.5 level, as table 2 shows), (b) the independent variable affects positively both mediating variables (broad-scope and interactive use of MAS) (figure 2 and table 3), (c) the mediating variables affect the dependent variable of strategic change, and (d) the effect of the independent variable (TMT risk taking decisions) on the dependent (strategic change) is less in the structural model (0.176) which includes both mediating variables, than in the single regression analysis (0.314). In other words, the inclusion of the two mediators in the proposed model leads to the significant reduction of the direct effect of the independent variable on the dependent variable but, simultaneously, increases its total effect, which is equal to its direct effect plus the sum of the indirect effects through the use of the interactive MAS and the indirect effects of broad-scope use of MAS (calculated as a multiplication of the statistically significant indirect effects on and from MAS use (Sarkar, et al., 2001).

${ }^{4}$ Baron and Kenny (1986) argue that four conditions must hold for testing mediating effects: (1) the independent variable must be significantly correlated with the dependent variable; (2) the independent variable must be significantly correlated with the mediator variable, and (3) the relationship between the independent and dependent variable must be weaker in (2) than in (1). 


\section{Conclusion}

The objective of this paper was twofold, to verify the relationship(s) between the three risk characteristics of the TMT as initially proposed by Sitkin and Pablo (1992) and later by Sitkin and Weingart (1995), and to improve our understanding of MAS as a mechanism that mediates the relationship between top management team risk characteristics and organizational strategic change. Broad-scope MAS and interactive use of MAS were argued to mediate the relationship between top management risk characteristics and the extent of strategic change. Our findings can be summarized as follows.

Regarding the relationship between the three risk characteristics the findings show a negative relationship between risk propensity and risk perception and a negative relationship between risk perception and risk taking decisions, coming in agreement with the findings of Sitkin and Weingart (1995), but also a significant positive relationship between risk propensity and risk taking, coming in agreement with the findings of Sitkin and Pablo (1992). In other words, risk taking characteristic (or risk decision making behavior as Sitkin and Weingart (1995) call it sometimes interchangeably) is determined by the other two risk characteristics of risk perception and risk propensity. Risk perception affects negatively risk taking directly while risk propensity affects risk taking twofold, one directly and positively, and one indirectly through risk perception. Consequently, our model's major relationship becomes the one between risk taking and strategic change(s).

Regarding the relationship between TMT risk decision making behavior (TMT risk taking) and strategic change, the findings show that TMT risk taking decision is positively related to the extent of strategic change, and especially for the strategic change towards prospector positions. This finding supports the idea that high risk taking decisions can be found in firms which are pioneers in change (Golder and Tellis, 1993; Narayanan, 2001; Min et al., 2006; Garret et al., 2009). We could not argue or draw separate conclusions for the relationship between TMT risk characteristics and strategic change for organizations moving towards defender positions, because these organizations constituted only the 5.68 percent of our total sample.

Regarding the relationship between TMT risk characteristics and MAS, the findings show that TMT risk taking decision is positively related to both the interactive and broad-scope use of MAS. This support the argument that MAS design and use is a relevant component of strategic management (Langfield-Smith, 1997; Gerdin and Greve, 2004; Naranjo-Gill and Hartmann, 2007) because top management formulate their strategic decisions through their search, interpretation and 'filtering' of information about the external and internal environment of their firms, typically 
provided by their established MAS (Hambrick and Mason, 1984; Knight et al., 1999; Miller et al., 1998; Abernethy and Brownell, 1999; Young et al., 2001; Chapman, 2010).

The results also support the ideas that the interactive use of MAS is essential for both enabling strategic change (Abernethy and Brownell, 1999; Abernethy and Lillis, 1995, 2001), and supporting innovation (Bisbe and Otley, 2004) because it involves dialogue and communication among top managers (Widener, 2006), as well as between top management and subordinates, which stimulates opportunity-seeking and encourages the emergence of new initiatives (Simons, 1995). Moreover, results support the arguments that broad scope MAS information is crucial for managerial decision making, especially when organizations are facing complex situations, high environmental dynamism and strategic uncertainty (Abernethy and Guthrie, 1994). Consequently, broad scope MAS information will be especially valued by TMTs, who are more inclined to change and innovation and take highly risky strategic decisions (Bantel and Jackson, 1989; Jensen and Zajac, 2004).

Regarding the relationships between MAS and strategic change, the findings show that broad-scope MAS is positively related to strategic change, mainly, for organizations moving towards prospector positions. These results are in line with Chenhall's (2003) arguments that broad-scope design of MAS overcomes the lack of relevance of narrow scope MAS information for managing flexibility, decentralization and innovation (Bisbe and Otley, 2004; Gerdin, 2005b; Hartmann, 2005). The results also show that the interactive use of MAS is also positively related to strategic change, mainly, for organizations moving towards prospector positions. This confirms the suggestions of Abernethy and Lillis (1995, 2001), and Bisbe and Otley (2004) mentioned earlier. Finally, we found a positive relationship between MAS scope and the interactive use of MAS, suggesting that the perceived usefulness of broad-scope affects the way in which the information is used.

Overall, we conclude that our results provide evidence for the mediating role of MAS use on the relationship between TMT risk taking decisions and strategic change. In this way we could give some answers to all these quests in the strategic management and management accounting literatures for a better understanding of the processes and arrangement through which organizations change their strategies (Carpenter et al., 2004; Luft and Shields, 2003; Miller et al., 1998; Rajagopalan et al., 1993; Chenhall and Langfield-Smith, 2003). We find that this mediating role concerns all large size companies in Greece, but is particularly prevalent for changes towards prospector positions, since 94.32 percent of the sample identified themselves as prospectors.

This paper has several limitations, beyond those typically related to the use of the questionnaire survey (Young, 1996). One of these limitations is the fact that the 
paper is not focused in one industry as Hambrick and Mason (1984, p 203) proposed because the sample would be quite small. Another limitation of this paper is its focus on top management teams 'as the sole custodians of strategy, ignoring the contributions of middle and lower level managers to the strategic process' (Nyamori et al., 2001, p. 72). Other groups of managers may influence the relationships studied as well.

This study is exploratory in nature and leaves ample room for future research. First, the findings of this study focus on the TMT, and future studies may look at the potential effects of other groups/levels of managers' risk characteristics on MAS use and strategic change. Also, other variables beyond risk characteristics could be analyzed for the TMT, such as the distribution of power and authority (Abernethy and Vagnoni, 2004). Further, other MAS design characteristics could be analyzed (e.g., timeliness, aggregation and integration, Chenhall and Morris, 1986), as well as specific management accounting techniques, such as the budgeting method, the use of ABC-costing or the use of scorecard-type instruments for performance appraisal. Finally, the path analyses explored here, that suggest mediation fit, could be complemented with tests for moderation forms of contingency fit, given that the proper theoretical foundation can be found (Hartmann and Moers, 1999, 2003; Gerdin and Greve, 2004).

\section{APPENDIX \\ MEASURES AND CONSTRUCT VALIDATION RESULTS}

\section{Content Validity}

Content validity refers to the agreement that exists among scholars about whether or not a scale is measuring what is supposed to measure. In our case most of the scales employed have been adopted from existing and validated scales used in the extant literature. However, the questionnaire was translated in to the Greek language, and thus, there was a discussion with professionals (academics and practitioners), in order to eliminate any wording problems (such as biased, ambiguous, inappropriate or double meaning items) and verify whether or not the questions were correctly translated and easily understood.

\section{Construct Validity}

Construct validity shows whether or not the chosen items are true measures of each construct (Straub, 1989). We tested the construct validity of our measures by employing confirmatory factor analysis (CFA) using AMOS 7.0 (see Figure A1). Unlike the traditional and more commonly used exploratory factor analysis (EFA), 
CFA contains inferential statistics that allow for hypothesis testing regarding the construct validity of a set of measures, leading to a stricter and more objective interpretation of validity than does EFA (Gerbing and Anderson, 1988). The indices used to assess the model are among the most frequently reported, namely Normed Fit Index (NFI), CFI (comparative Wt index), and RMSEA (root mean square error of approximation). The threshold values recommended are (i) NFI> 0.90 (Bentler and Bonett, 1980) and (ii) CFI > 0.95 (Hu and Bentler, 1999), and (iii) RMSEA < 0.10 (Browne and Cudeck, 1993).

Convergent validity relates to the extent that many methods of measuring a variable gives the same result (Churchill, 1979). Convergent validity was examined by computing the indexes of average variance extracted that is the amount of construct variance relative to measurement error. An average variance extracted of at least 0.50 (i.e., 50 percent) provides support for convergent validity (Gerbing and Anderson, 1988; Fornell and Larcker, 1981) (table A2)

Construct reliability was assessed using Cronbach's a-value. In order to test the convergent validity of the measurement models, the methodology suggested by Fornell and Larcker (1981), which includes the estimation of the items squared factor loadings (greater than 0.5 are considered very significant), the composite reliability for each construct (has to exceed the threshold of 0.70), and the extracted variance for all constructs (greater than 0.50) (table A2).

Finally, Discriminant validity is concerned with the degree to which a variable measures a concept that is uniquely defined and is not highly correlated with other variables included in the model. The discriminant validity of variables is considered acceptable when the correlation between two variables is less than the average variance extracted (Fornell and Larcker, 1981) (table A1):

Table A1: Discriminant Validity

\begin{tabular}{|c|c|c|c|c|}
\hline & 1. & 2. & 3. & 4. \\
\hline 1. Risk Propensity & 0.883 & & & \\
\hline 2. Risk Perception & $-0.259 *$ & 0.877 & & \\
\hline 3. Interactive Use of MAS & & & 0.872 & \\
\hline 4. Use of Broad-Scope MAS & & & $0.524 * *$ & 0.883 \\
\hline
\end{tabular}

*Correlation is significant at the 0.05 level

**Correlation is significant at the 0.01 level 
Figure A1: Confirmatory Factor Analysis (The Metric Model).

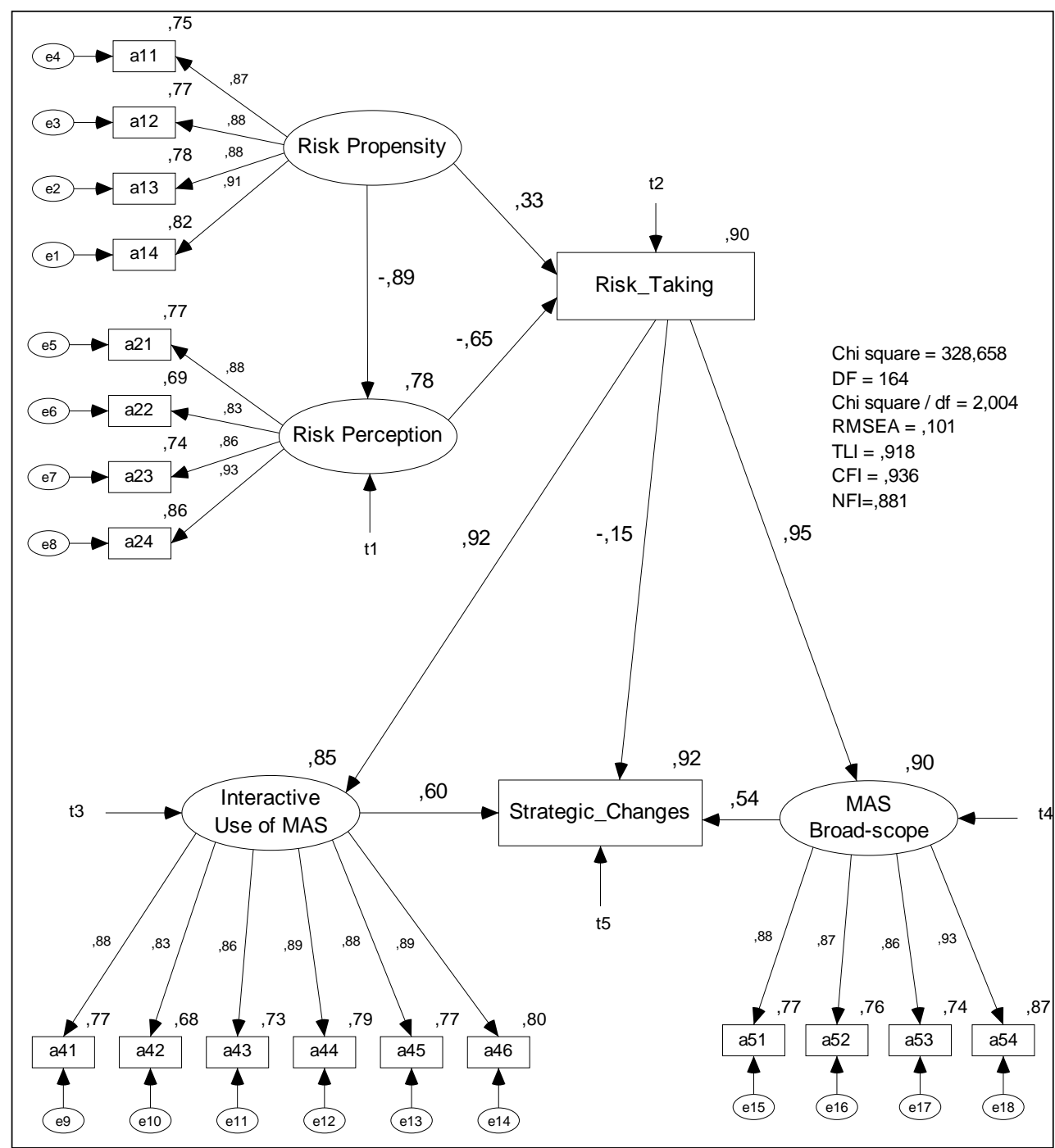


Table A2: Convergent validity - Construct reliability.

\begin{tabular}{|c|c|c|c|c|c|}
\hline \multirow[b]{2}{*}{$\stackrel{\mathscr{E}}{\stackrel{\Xi}{E}}$} & \multirow[b]{2}{*}{$\frac{n}{\stackrel{n}{E}}$} & \multicolumn{4}{|c|}{ CFA Model } \\
\hline & & $\stackrel{\infty}{\overrightarrow{1}}$ & 兄 & $\stackrel{1}{\&}$ & $\begin{array}{l}\pi \\
n \\
0 \\
\tilde{0} \\
\tilde{J} \\
0 \\
0 \\
0 \\
0\end{array}$ \\
\hline $\begin{array}{l}\text { Choose less risky alternatives to ensure financial security } \\
\text { (R) }\end{array}$ & \multirow{4}{*}{ 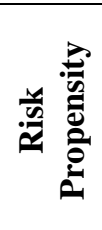 } & .75 & \multirow{4}{*}{0.94} & \multirow{4}{*}{$78 \%$} & \multirow{4}{*}{.93} \\
\hline Choose riskier alternatives to maximize potential gains & & .77 & & & \\
\hline Choose riskier alternatives to achieve financial goals & & .78 & & & \\
\hline Choose less risky alternatives to stabilize financial status (R) & & .82 & & & \\
\hline Selling products in foreign markets implies high risk & \multirow{4}{*}{ 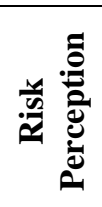 } & .77 & \multirow{4}{*}{0.93} & \multirow{4}{*}{$77 \%$} & \multirow{4}{*}{.92} \\
\hline Exports are an important opportunity for my firm & & .69 & & & \\
\hline International activity is a positive thing in my business & & .74 & & & \\
\hline My firm has a high probability of success in foreign markets & & .86 & & & \\
\hline Setting and negotiating goals and targets & \multirow{6}{*}{ 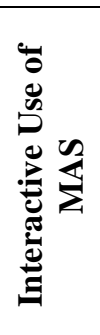 } & .77 & \multirow{6}{*}{0.95} & \multirow{6}{*}{$76 \%$} & \multirow{6}{*}{.95} \\
\hline Encouraging new goals and priorities & & .68 & & & \\
\hline Signalling key strategic areas for improvement & & .73 & & & \\
\hline Encouraging new ideas and actions for doing tasks & & .79 & & & \\
\hline $\begin{array}{l}\text { Involving subordinates in face-to-face permanent } \\
\text { discussions }\end{array}$ & & .77 & & & \\
\hline Use of MAS as a learning tool & & .80 & & & \\
\hline Future-oriented information & \multirow{4}{*}{ 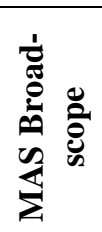 } & .77 & \multirow{4}{*}{0.94} & \multirow{4}{*}{$78 \%$} & \multirow{4}{*}{.93} \\
\hline External information & & .76 & & & \\
\hline Non-financial information & & .74 & & & \\
\hline Long-run oriented information & & .87 & & & \\
\hline
\end{tabular}

(Squared Factor Loadings (SFL's) for each construct, Composite Reliability (CR), Average Variance Extracted (AVE), and Cronbach's a-value of each construct should be greater than 0.5, 0.7, 0.5 and 0.7 respectively. (Hair, Anderson, Tatham, and Black, 1988; Nunnally and Bernstein, 1994). 
Table A3: Demographic Characteristics

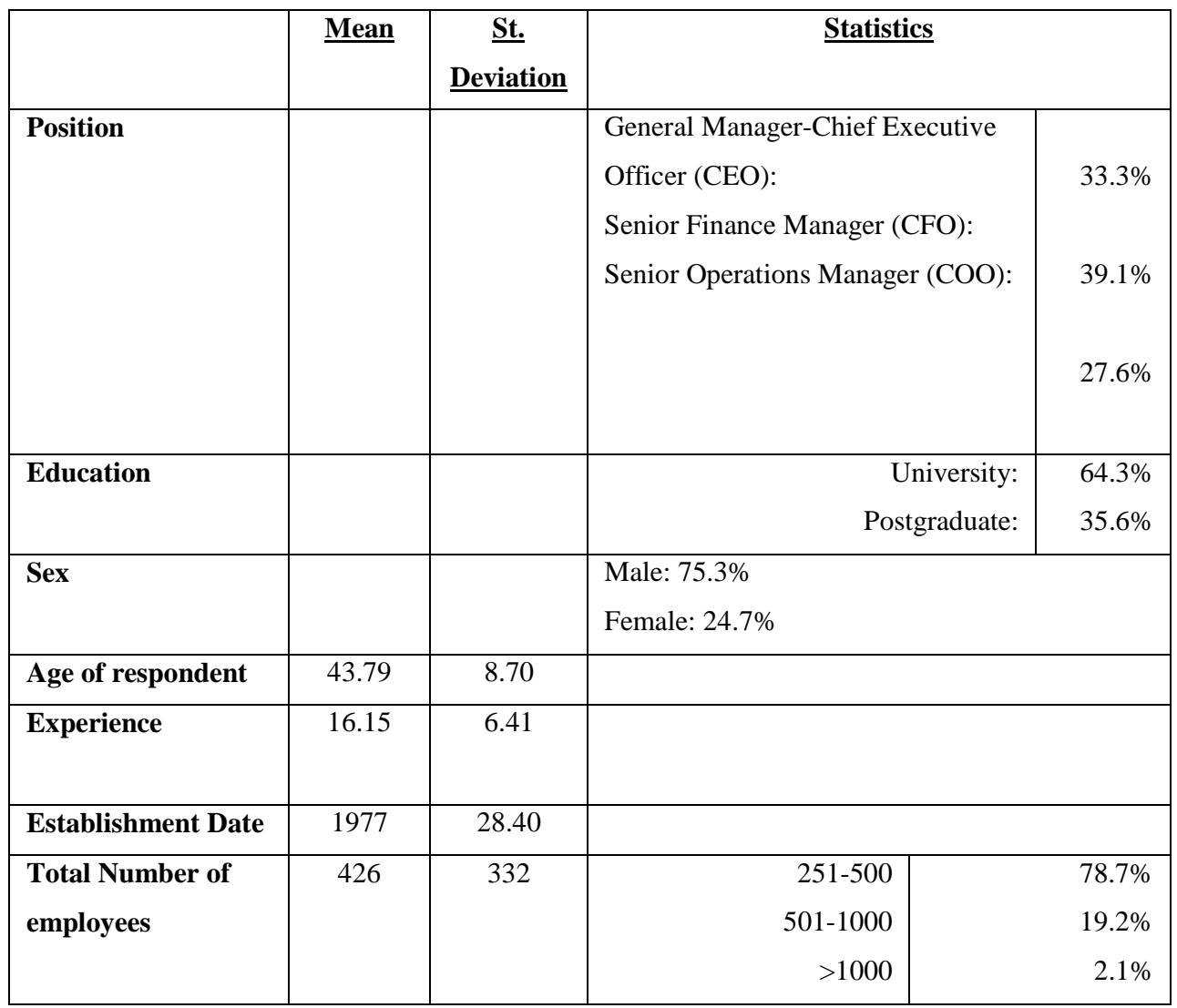

\section{References}

Abernethy, M. A., and Brownell, P. (1999). "The role of budgets in organizations facing strategic change: an exploratory study". Accounting, Organizations and Society, 24, 189-204.

Abernethy, M. A., and Brownell, P. (1997). "Management Control Systems in Research and Development Organizations: The Role of Accounting, Behavior and Personnel Control". Accounting, Organizations and Society, 22, 233-49.

Abernethy, M. A. and Guthrie, C. H. (1994). "An empirical assessment of the "fit" between strategy and management information system design". Accounting and Finance, 34, 4966.

Abernethy, M. A. and Lillis, A. M. (1995). "The impact of manufacturing flexibility on management controls system design." Accounting, Organizations and Society, 20 (4), 241-258. 
Abernethy, M. A. and Lillis, A. M. (2001). "Interdependencies in organization design: a test in hospitals". Journal of Management Accounting Research, 13, 107-129.

Abernethy, M. A. and Vagnoni, E. (2004). "Power, organization design and managerial behaviour". Accounting, Organizations and Society, 29(3-4), 207-225.

Ahrens, T. and Chapman, C. (2002). "The Structuration of Legitimate Performance Measures and Management: Day-to-Day Contests of Accountability in a U.K. Restaurant Chain". Management Accounting Research, 13 (2), 1-21.

Ahrens, T. and Chapman, C. (2004). "Accounting for Flexibility and Efficiency: A Field Study of Management Control Systems in a Restaurant Chain". Contemporary Accounting Research, 21 (2), 271-301.

Allen, K. R. (2003). “Bringing new technology to market”. Upper Saddle River, NJ: Prentice Hall.

Anderson, J. and Gerbing, D., (1988). "Structural equation modeling in practice: a review and recommended two-step approach". Psychological Bulletin, 103(3), 411-423.

Antonides, G. and Van der Sar, N. L. (1990). "Individual expectations, risk perception and preferences in relation to investment decision making". Journal of Economic Psychology, 11, 227-245.

Anthony, R. N. (1965). "The Management Control Function", Boston, MA: Harvard Business School Press.

Armstrong, J.S. and Overton T. (1977). "Estimating nonresponse bias in mail surveys." Journal of Marketing Research, 14: 396-402.

Ashby, W. R. (1960). "Design for a Brain: The Origin of Adaptive Behavior". New York: John Wiley.

Audia P.G., Locke E.A. and Smith K.G. (2000). "The paradox of success: an archival and a laboratory study of strategic persistence following radical environmental change". Academy of Management Journal, 43(5), 837-53.

Bantel, K. A. and Jackson, S. E. (1989). "Top management and innovations in banking: does the composition of the top team make a difference?". Strategic Management Journal, 10(S1), 107-124.

Baron, R. M. and Kenny, D. A. (1986). "The Moderator-Mediator Variable Distinction in Social Psychological Research: Conceptual, Strategic, and Statistical Considerations". Journal of Personality and Social Psychology, 51(6), 1173-1182.

Basu, A., Osland A., and Solt, M. (2008). "A New Course on Sustainability Entrepreneurship". The NCIIA 12th Annual Meeting (pp. 71-78). Massachusetts : National Collegiate Inventors and Innovators Alliance.

Bentler, P. M. and Bonett, D. G. (1980). "Significance tests and goodness of fit in the analysis of covariance structures". Psychological Bulletin, 88, 588-606.

Bisbe, J. and Otley, D. (2004). "The effects of the interactive use of management control systems on product innovation". Accounting, Organizations and Society, 29, 709-737.

Bouwens J. and Abernethy M. A. (2000). "The consequences of customization on management accounting systems design.", Accounting, Organizations and Society, 25(3), 221-259.

Brockhaus, R.H. (1980). "Risk, taking propensity of entrepreneurs". Academy of Management Journal, 23 (3), 509-520.

Bromily, P., and Curley, S.P. (1992). Individual differences in risk taking. In: Yates, J.F. (Ed.), Risk-Taking Behavior. Wiley, Chichester, pp. 88-132. 
Brouthers K.D. (1995). "The influence of international risk on entry mode strategy in the computer software industry". Manage. Int. Rev. 35 (1), 7-28.

Brown, S. L. and Eisenhardt, K. M. (1997). "The Art of Continuous Change: Linking Complexity Theory and Time-Paced Evolution in Relentlessly Shifting Organizations". Administrative Science Quarterly, 42, 1-34.

Browne, M. W. and Cudeck, R. (1993). "Alternative ways of assessing model fit". In K. A. Bollen and J. S. Long (Eds.), Testing structural equation models (pp. 136-162). Newbury Park, CA: Sage.

Burgelman, R. A. (2002). “Strategy is Destiny: How Strategy-Making Shapes a Company's Future". New York: Free Press.

Burns, T. and Stalker, G. M. (1961). "The Management of Innovation”. London: Tavistock.

Cardinal, L. (2001). "Technological Innovation in the Pharmaceutical Industry: The Use of Organizational Control in Managing Research and Development". Organization Science, 12(1), 19-36.

Carpenter, M. A., Geletkanycz, M. A., and Sanders, W. G. (2004). "Upper echelons research revisited: antecedents, elements, and consequences of top management team composition." Journal of Management, 30(6), 749-778.

Carpenter, G.S. and Nakamoto, K. (1989). "Consumer preference formation and pioneering advantage". Journal of Marketing Research, 26(3), 285-98.

Chapman, C. S. (1997). "Reflections on a contingent view of accounting". Accounting, Organizations and Society, 22, 189-205.

Chapman, C. S. (1998). "Accountants in Organizational Networks". Accounting, Organizations and Society, 23 (8), 737-66.

Chapman, C. S. (2010). “Controlling Strategy: Management, Accounting, and Performance Measurement". Oxford: Oxford University Press.

Chen, C. (2009). "Technology commercialization, incubator and venture capital, and New Venture performance”. Journal of Business Research, 62 (1), 93-103.

Chenhall, R. H. (2003). "Management control systems design within its organizational context: findings from contingency-based research and directions for the future". Accounting, Organizations and Society, 28, 127-168.

Chenhall,R. (2005). "Content and Process Approaches to Studying Strategy and Management Control", in C. Chapman (ed.), Controlling Strategy: Management, Accounting and Performance. Oxford: Oxford University Press.

Chenhall, R. H. and Morris, D. (1986). "The impact of structure, environment and interdependence on the perceived usefulness of management accounting systems". The Accounting Review, 61, 16-35.

Chenhall,R., and Langfield-Smith, K., (1998). "Adoption and benefits of management accounting practices: An Australian study". Management Accounting Research, 9, 1-19.

Chenhall, R. H. and Langfield-Smith, K. (2003). "Performance measurement and reward systems, trust and strategic change". Journal of Management Accounting Research, 15, $117-143$.

Child, J. (1972). "Organization structure, environment and performance: the role of strategic choice." Sociology, 6(1), 1-22.

Churchill, G.A., (1979). "A paradigm for developing better measures of marketing constructs". Journal of Marketing Research, 16 (1), pp. 64-73.

Cooper, R. G. (1995). "Developing New Products on Time, in Time". Research Technology Management, 38, 49-57. 
Cronbach, L.J. (1951). "Coefficient alpha and the internal structure of a test." Psychometrika, 16 , pp. 297-334.

Cyert, R. M., and March, J. G. ( 1963). A behavioral theory of the firm. Englewood Cliffs, N. J.: Prentice-Hall.

Danneels, E. (2002). "The dynamics of product innovation and firm competences." Strategic Management Journal, 23, 1095-1121.

Davila, T. (2000). "An Empirical Study on the Drivers of Management Control Systems' Design in New Product Development". Accounting, Organizations and Society, 25(4/5), 383-409.

Dunegan, K., Duchon, D. and Barton, S. (1992). "Affect, risk, and decision criticality: replication and extension in a business setting". Organizational Behavior and Human Decision Processes, 53 (3), 335-351.

Eccles, R. Cr. (1991). "The performance measurement manifesto". Harvard Business Review (Jan-Feb), 131-137.

Farmer, T.A. (1993). "Testing the effect of risk attitude on auditor judgments using multiattribute utility theory". Journal of Accounting, Auditing, and Finance, 8(1), 91114.

Feldman, M. S. and Rafaeli, A. (2002). "Organizational Routines as Sources of Connections and Understandings". Journal of Management Studies, 39, 309-32.

Finkelstein, S., and Hambrick, D. C. (1990). "Top-management-team tenure and organizational outcomes: The moderating role of managerial discretion". Administrative Science Quarterly, 35: 484-503.

Finkelstein, S. and Hambrick, D. C. (1996). "Strategic leadership: top executives and their effects on organizations". St. Paul, Minneapolis: West Publishing Company.

Fiol, C. M. (1996). "Squeezing Harder Doesn't Always Work: Continuing the Search for Consistency in Innovation Research". Academy of Management Review, 21(4), 1012-21.

Fishburn, P.C. (1977). "Mean-risk analysis with risk associated with below-target returns". American Economic Review, 67 (2), 116-126.

Forlani, D. and Mullins, J.W. (2000), "Perceived risks and choices in entrepreneurs' new venture decisions", Journal of Business Venturing, 15 (4), 305-322.

Fornell, C. and Larcker, D. F. (1981). "Evaluating structural equation models with unobservable variables and measurement error". Journal of Marketing Research, 18 (2), $39-50$.

Frow, N., Marginson, D., and Ogden, S. (2005). Encouraging strategic behaviour while maintaining management control: multi-functional project teams, budgets, and the negotiation of shared accountabilities in contemporary enterprises. Management Accounting Research, 16(3), 269-292.

$\mathrm{Fu}$, J. (1993). "Increased risk aversion and risky investment". The Journal of Risk and Insurance, 60 (3), 494-501.

Garret R., Covin J. and Slevin D. (2009). "Market responsiveness, top management risk taking, and the role of strategic learning as determinants of market pionnering". Journal of Business Research, 62, 782-788

Gavetti, G. and Levinthal, D. (2000). "Looking Forward and Looking Backward: Cognitive and Experiential Search". Administrative Science Quarterly, 45, 113-37.

Gerbing D.W. and Anderson, J. C., (1988). "An updated paradigm for scale development incorporating unidimensionality and its assessment". Journal of Marketing Research, 25: $186-192$. 
Gerdin, J. (2005a). "Management accounting system design in manufacturing departments: an empirical investigation using a multiple contingencies approach.", Accounting, Organizations and Society, 30(2), 99-126.

Gerdin, J. (2005b). "The impact of departmental interdependencies and management accounting system use on subunit performance". European Accounting Review, 14, 297-328.

Gerdin, J., and Greve, J. (2004). "Forms of contingency fit in management accounting research - a critical review". Accounting, Organizations and Society, 29, 303-326.

Ghosh, D. and Ray, M.R. (1992). "Risk attitude, ambiguity intolerance and decision making: an exploratory investigation". Decision Sciences, 23 (2), 431-444.

Golden, B. R. and Zajac, E. J. (2001). "When will boards influence strategy? Inclination x power = strategic change". Strategic Management Journal, 22(12), 1087-1111.

Golder, P.N. and Tellis, G.J. (1993). "Pioneer advantage: marketing logic or marketing legend". Journal of Marketing Research, 30(2), 158-70.

Gul, F. A. (1991). "The effects of management accounting systems and environmental uncertainty on small business manager's performance". Accounting and Business Research, 22(4), 57-61.

Gul, F. A., and Chia, Y. M. (1994). The effects of management accounting systems, perceived environmental uncertainty and decentralization on managerial performance: a test of three-way interaction. Accounting, Organizations and Society, 19, 413-426.

Gupta, P.K. (2004). "Enterprise risk management - sub-optimality to optimality", Journal of Insurance and Risk Management, Vol. II No.4,

Hair, F., Anderson, R., Tatham, R. and Black, W. (1998). "Multivariate Data Analysis with Readings.”, 5th edn. Upper Saddle River, NJ: Prentice-Hall International.

Haleblian, J., and Finkelstein, S. (1993). "Top-management team size, CEO dominance, and firm performance: The moderating roles of environmental turbulence and discretion". Academy of Management Journal, 36: 844-863.

Hambrick, D. C. (1994). Top management groups: A conceptual integration and reconsideration of the "team" label. In B. Staw and L. L. Cummings (Eds.), Research in Organizational Behavior: Vol. 16. 171-213. Beverly Hill: JAI Press.

Hambrick, D. C., and Mason, P. A. (1984). Upper echelons: The organization as a reflection of its top managers. Academy of Management Review, 9: 193-206.

Harnett, D.L. and Cummings, L.L. (1980). "Bargaining Behavior: An International Study”. Dame Publications, Houston.

Hartmann, F. G. H. (2005). "The impact of departmental interdependencies and management accounting system use on subunit performance: a comment". European Accounting Review, 14, 329-334.

Hartmann, F. G. H. and Moers, F. (1999). "Testing contingency hypotheses in budgetary research using moderated regression analysis". Accounting, Organizations and Society, 24, 291-315.

Hartmann, F. G. H. and Moers, F. (2003). "Testing contingency hypotheses in budgetary research using moderated regression analysis: a second look". Accounting, Organizations and Society, 28, 185-191.

Henri, J. F. (2006). "Management control systems and strategy: a resource-based perspective”. Accounting, Organizations and Society, 31(6), 529-558.

Higbee, K.L. (1971. "Expression of Walter Mitty-ness in actual behavior'. Journal of Personality and Social Psychology, 20 (3), 416-422. 
Hoskisson, R. E., Hitt, M. A., Wan, W. P. and Yiu, D. (1999). "Theory and Research in Strategic Management: Swings of a Pendulum”. Journal of Management, 25(3), 417-56.

Hrebiniak, L. G., and Joyce, W. F. (1985). "Organizational adaptation: strategic choice and environmental determinism". Administrative Science Quarterly, 30, 336-349.

Hu, L.T. and Bentler, P. M. (1999). "Cutoff criteria for fit indexes in covariance structure analysis: Conventional criteria versus new alternatives", Structural Equation Modeling: A Multidisciplinary Journal, 6(1), 1-55.

Hunt, S. (1990). "Commentary on an Empirical Investigation of a General Theory of Marketing Ethics." Journal of the Academy of Marketing Science, 18 (2), 173-177.

Jackson, S. (1992). Consequences of group composition for the interpersonal dynamics of strategic issue processing. In P. Shrivastava, A. Huff, and J. Dutton (Eds.), Advances in strategic management: 345-382. Greenwich, CT: JAI Press.

Jackson, D.N., Hourany, L. and Vidmar, N.J. (1972). "A four-dimensional interpretation of risk taking”. Journal of Personality, 40 (3), 483-501.

Jarzabkowski, P., and Searle, R. H. (2005). "Harnessing diversity and collective action in the top management team". Long Range Planning, 37, 399-419.

Jensen, M. and Zajac, E. J. (2004). "Corporate elites and corporate strategy: how demographic preferences and structural position shape the scope of the firm". Strategic Management Journal, 25(6), 507-524.

Jorion, P. (2001). "Value at Risk - The New Benchmark for Managing Financial Risk", McGraw-Hill, New York, NY.

Kahneman, D. and Tversky, A. (1979). "Prospect theory: An analysis of decision under risk". Econometrica, 47: 263-291.

Keil, M., Wallace, L., Turk, D., Dixon-Randall, G. and Nulden, U. (2000), "An investigation of risk perception and risk propensity on the decision to continue a software development project", The Journal of Systems and Software, 53 (2), 145-157.

Keinan, G., Meir, E. and Gome-Nemirovsky, T. (1984). "Measurement of risk takers' personality". Psychological Reports, 55 (1), 163-167.

Kerin, R.A., Varadarajan, R.P. and Peterson, R.A. (1992). "First-mover advantage: a synthesis, conceptual framework, and research propositions". Journal of Marketing, 56(4), 33-52.

Keyes, R., (1985). “Chancing It: Why We Take Risks”. Little Brown and Company, Boston.

Kim, D.C. (1992). "Risk preferences in participative budgeting". The Accounting Review, 67 (2), 303-318.

Knight, D., Pearce, C. L., Smith, K. G., Olian, J. D., Sims, H. P., Smith, K. A. and Flood, P. (1999). "Top management team diversity, group process, and strategic consensus". Strategic Management Journal, 20(5), 445-465.

Koellinger, P., Minniti, M. and Schade, C. (2007). "I think I can, I think I can: Overconfidence and entrepreneurial behavior". Journal of Economic Psychology, 28, 502-527.

Kogan, N. and Wallach, M.A. (1964). "Risk Taking: A Study in Cognition and Personality". Holt, Rinehart and Winston, New York.

Krueger, N. and Dickson, P.R. (1994). "How believing in ourselves increases risk taking: perceived self-efficacy and opportunity recognition". Decision Sciences 25 (3), 385400. 
Kwon, K. N. and Lee J. (2009). "The effects of reference point, knowledge, and risk propensity on the evaluation of financial products". Journal of Business Research, 62, $719-725$.

Lam, J. (2006). Managing risk across the enterprise: Challenges and benefits. In: Ong, M. (Ed.), Risk Management, A Modern Perspective, 1st ed. Elsevier, Burlington, MA.

Langfield-Smith, K. (1997). "Management control systems and strategy: a critical review". Accounting, Organizations and Society, 22(2), 207-232.

Lant, T. K., and Montgomery, D. B. (1987). "Learning from strategic success and failure". Journal of Business Research, 15, 503-518.

Lawrence, B. S. (1997). "The black box of organizational demography". Organization Science, 8, 1-22.

Li, X. (2009). "Corporate risk management and investment decisions", The Journal of Risk Finance, 10(2), 155-68.

Lorange, P., Scott-Morton, M. E. and Goshal, S. (1986). "Strategic Control”. St Paul, MN: West Publishing.

Luft, J. and Shields, M. D. (2003). "Mapping management accounting: graphics and guidelines for theory-consistent empirical research". Accounting, Organizations and Society, 28, 169-249.

Lukka, K. (1988). "Budgetary Biasing in Organizations: Theoretical Framework and Empirical Evidence”. Accounting, Organizations and Society, 13 (3), 281-301.

MacCrimmon, K.R. and Wehrung, D.A. (1985). "A portfolio of risk measures". Theory and Decision, 19 (1), 1-29.

MacCrimmon, K.R. and Wehrung, D.A. (1990). "Characteristics of risk taking executives". Management Science, 36 (4), 422-435.

Malina, M. A. and Selto, F. H. (2001). "Communicating and controlling strategy: an empirical study of the effectiveness of the balanced scorecard". Journal of Management Accounting Research, 13, 47-90.

March, J.G. and Shapira, Z. (1987). "Managerial perspectives on risk and risk taking". Management Science, 33 (11), 1404-1418.

McGrath, M. D. (1995). "Product Strategy for High-Technology Companies". New York: Irwin.

Mia, L. and Chenhall, R. H. (1994). "The usefulness of management accounting systems, functional differentiation and managerial effectiveness". Accounting, Organizations and Society, 19(1), 1-13.

Miles, R. E. and Snow, C. C. (1978). “Organizational strategy, structure, and process.” New York: McGraw-Hill Book Company.

Miller, D. and Friesen, P. H. (1982). "Innovation in Conservative and Entrepreneurial Firms: Two Models of Strategic Momentum". Strategic Management Journal, 3(1), 1-25.

Miller, C., Burke, L. and Glick, M. (1998). "Cognitive diversity among upper-echelon executives: implications for strategic decision processes". Strategic Management Journal, 19(1), 39-58.

Min, S., Kalwani, M.U. and Robinson, W.T. (2006). "Market pioneer and early follower survival risks: a contingency analysis of really new versus incrementally new productmarkets". Journal of Marketing,70(1), 15-33.

Miner, A. S., Bassoff, P. and Moorman, C. (2001). "Organizational Improvisation and Learning: A Field Study". Administrative Science Quarterly, 46, 304-37. 
Modell, S. (2004). "Performance measurement myths in the public sector: a research note.", Financial Accountability and Management, 20(1), 39-55.

Naranjo-Gil, D. and Hartmann, F. (2007). "Management accounting systems, top management team heterogeneity and strategic change", Accounting, Organizations and Society 32 (7-8), 735-756

Narayanan, V.K. (2001). "Managing technology and innovation for competitive advantage", Prentice Hall, Upper Saddle River: NJ.

Nixon, B. (1998). "Research and Development Performance Measurement: A Case Study". Management Accounting Research, 9, 329-55.

Norburn, D. (1989). 'The chief executive: A breed apart'. Strategic Management Journal, 10(1), 1-15.

Nunnally J. C., (1978). "Psychometric Theory”, 3rd edition. McGraw-Hill: New York.

Nunnally, J.C. and Bernstein, I.H. (1994), "Psychometric Theory”, 3rd ed., McGraw-Hill, New York.

Nyamori, R. O., Perera, M. H. B., and Lawrence, S. R. (2001). "The concept of strategic change and implications formanagement accounting research." Journal of Accounting Literature, 20. 62-83.

Perera, S., Harrison, G. and Poole, M. (1997). "Customer-focused manufacturing strategy and the use of operation-based nonfinancial performance measures: a research note". Accounting, Organizations and Society, 22(6), 557-572.

Peterson, R. S., Smith, D. B., Martorana, P. V., and Owens, P. D. (2003). "The impact of chief executive officer personality on top management team dynamics: One mechanism by which leadership affects organizational performance". Journal of Applied Psychology, 88: 795-808.

Priem, R. L., Lyon, D. W., and Dess, G. G. (1999). Inherent limitations of demographic proxies in top management team heterogeneity research. Journal of Management, 25 : 935-953.

Rajagopalan, N., Rasheed, A. M. and Datta, D. K. (1993). "Strategic decision processes: critical review and future directions". Journal of Management, 19, 349-384.

Robinson W.T. and Min, S. (2002). "Is the first to market the first to fail? Empirical evidence for industrial goods businesses". Journal of Marketing Research, 39(1), 120-8.

Sarkar, M. B., Echambadi, R., Cavusgil, S. T. and Aulakh, P. S. (2001). "The influence of complementarity, compatibility, and relationship capital on alliance performance". Academy of Marketing Science Journal, 29(4), 358-373.

Saunders, M., Lewis, P., Thornhill, A. (2000). "Research Methods for Business Students”, 2nd edition. London: Pearson Education.

Schneider, S.L. and Lopes, L.L. (1986). "Reflection in preferences under risk: who and when may suggest why". Journal of Experimental Psychology: Human Perception and Performance, 12 (4), 535 \pm 548.

Shimpi, P.A. (2001). "Integrating Corporate Risk Management”, Texere, New York, NY.

Shortell, S. M. and Zajac, E. (1990). "Perceptual and archival measures of Miles and Snow's strategic types: a comprehensive assessment of reliability and validity". Academy of

Management Journal, 33, 817-832.

Simon, M., Houghton, S. and Aquino, K. (2000). "Cognitive biases, risk perception and venture formation", Journal of Business Venturing, 15, 113-134.

Simons,R. (1994). "How new managers use control systems as levers of strategic renewal", Strategic Management Journal, Vol. 15, 169-189. 
Simons, R. (1995). "Levers of control: how managers use innovative control systems to drive strategic renewal." Boston, MA: Harvard Business School Press.

Simons, R. (2000). "Performance measurement and control systems for implementing strategies". Upper Saddle River: Prentice Hall.

Sitkin, S.,B. and Pablo, A. L. (1992). "Reconceptualizing the determinants of risk behavior", Academy of Management Review, 17 (1), 9-38.

Sitkin, S.,B., Weingart, L.,R. (1995). "Determinants of risky decision-making behavior: a test of the mediating role of risk perceptions and propensity." Academy of Management 38 (6), 1573-1592.

Skipper, H.D. (1997). “International Risk and Insurance”, McGraw-Hill, New York, NY.

Slovic, P. (1962). "Convergent validation of risk taking measures". Journal of Abnormal and Social Psychology, 65 (1), 68-71.

Straub, D. W., (1989). “Validating Instruments in MIS Research.” MIS Quarterly, 12 (2): 147-169.

Staw, B.M., Sandelands, L.E. and Dutton, J.E. (1981). "Threat-rigidity effects in organizational behavior: a multilevel analysis". Administrative Science Quarterly, 26 (4), 501-524.

Sutcliffe, K.M. (1994). "What executives notice: accurate perceptions in top management teams". Academy of Management Journal 37 (5), 1360-1378.

Taylor, R.N. and Dunnette, M.D. (1974). "Relative contribution of decision-maker attributes to decision processes". Organizational Behavior and Human Performance, 12, 286-298.

Vlek, C. and Stallen, P.J. (1980). "Rational and personal aspects of risk". Acta Psychologica, 45, 273-300.

Widener, S. K. (2006). “An empirical analysis of the levers of control framework.”, In Working paper presented at AAA conference in Tampa, Florida, January 2006.

West, S. G., Finch, J. F. and Curran, P. J. (1995). "Structural equation models with nonnormal variables: Problems and remedies", in Hoyle, R. H. (ed.) "Structural Equation Modelling: Concepts, Issues, and Applications", Thousand Oaks, CA: Sage Publications.

Wiersema, M. F., and Bantel, K. A. (1992). "Top management team demography and corporate strategic change". Academy of Management Journal, 35(1), 91-121.

Willebrands, D., Lammers, J. and Hartog, J. (2011). "A successful businessman is not a gambler. Risk attitude and business performance among small enterprises in Nigeria". Journal of Economic Psychology, doi:10.1016/j.joep.2011.03.006.

Young, S. M. (1996). "Survey research in management accounting: a critical assessment. In Richardson, A. J. (Ed.), Research methods in accounting (pp. 55-68).

Young, G., Charns, M. and Shortell, S. (2001). "Top manager and network effects on the adoption of innovative management practices: a study of TQM in a public hospital system". Strategic Management Journal, 22(10), 935-951.

Zikmund, W.G. (2003). "Business research methods”, 7th edition. Mason: Thomson, SouthWestern.

Zirger, B. J. and Maidique, M. A. (1990). "a Model of New Product Development: An Empirical test”. Management Science, 36 (7), 867-84. 